\title{
Gambaran Tingkat Kepuasan Pasien dalam Penanganan Keluhan (Service Recovery) Rawat Inap di RSUD Rasidin Kota Padang
}

R Nona Millani, ${ }^{1}$ Rima Semiarty, ${ }^{2}$ Rizanda Machmud ${ }^{2}$

\begin{abstract}
Abstrak
Penanganan keluhan di RSUD Rasidin masih menjadi permasalahan, karena hasil observasi tahun 2018 terdapat beberapa keluhan pasien terhadap pelayanan di ruang rawat inap. Hal ini dapat dilihat dari survey Indeks Kepuasan Masyarakat terhadap penanganan keluhan masih dibawah standar yaitu 76,56 artinya kinerja dari unit pelayanan masih kurang baik. Tujuan: Menganalisis tingkat kepuasan pasien dalam penanganan keluhan (Service Recovery) di RSUD Rasidin Kota Padang. Jenis penelitian ini merupakan penelitian cross sectional dengan instrument penelitian kuisioner terhadap 155 responden rawat inap di RSUD Rasidin Kota Padang. Variabel yang diukur yaitu Procedural Justice, Interactional Justice dan Distributive Justice. Analisis data menggunakan importance performance analysis dengan diagram kartesius sehingga didapatkan pemetaan alur permasalahan. Hasil: Ada 26\% responden mendapat pelayanan kurang baik dan masih ada beberapa keluhan yang harus menjadi prioritas utama untuk ditingkatkan dari atribut Interactional Justice dan Distributive Justice diantaranya keahlian dokter dalam memberikan informasi mengenai masalah kesehatan penyakit yang diderita pasien, keahlian doker dalam menanyakan keluhan pasien, keahlian perawat dalam memberikan informasi mengenai masalah kesehatan penyakit yang diderita pasien, dan komunikasi antara pasien dengan dokter. Simpulan: Keempat atribut ini lebih menekankan kepada perilaku dan komunikasi yang kurang baik antara tenaga medis dengan pasien.
\end{abstract}

Kata kunci: keluhan, penanganan keluhan, RSUD Rasidin

\begin{abstract}
Service Recovery in RSUD Rasidin is still a problem, because observations result in 2018 there are some patient complaints about services in the inpatient room. This can be seen on the survey of Community Satisfaction Index on handling complaints which is still below the standard, with value 76.56, the performance of service unit is still not good enough. Objectives: To analyzed the Service Recovery of inpatients in RSUD Rasidin, Padang City. This type of research was a cross-sectional study with questionnaire research instruments on 155 respondents hospitalized in Rasidin General Hospital, Padang City. Variables were Procedural Justice, Interactional Justice and Distributive Justice. Data analysis using importance-performance analysis with a Cartesian diagram so that the problem flow mapping is obtained. Results: There were $26 \%$ of respondents get poor service and there were some complaints that should be the top priority to be improved from the Interactional Justice and Distributive Justice attributes including the doctor's expertise in providing information on the health problems of patients, doctor's expertise in asking patient complaints, nurses' expertise in providing information about health problems suffered by patients, and communication between patients and doctors. Conclusions: Four attributes emphasize behavior and poor communication between medical personnel and patients.
\end{abstract}

Keywords: complaints, handling complaints, rasidin general hospital

Affiliasi penulis: 1 Prodi Magister Kesehatan Masyarakat Fakultas Kedokteran Universitas Andalas Padang (FK Unand), 2. Bagian IImu Kesehatan Masyarakat FK Unand
Korespondensi : Rima Semiarty, Email: rimasemiarty@med.unand. ac.id Telp: +62 85271555150 


\section{PENDAHULUAN}

Penanganan keluhan adalah suatu hal yang akan dilakukan perusahaan ketika adanya keluhan dari pelanggan yang merasa tidak puas akan layanan perusahaan penyedia jasa atau setelah terjadinya suatu kegagalan layanan. Penanganan keluhan yang baik sebagai salah satu strategi dalam meningkatkan pelayanan dan mempertahankan hubungan baik dengan para pelanggan. Penanganan keluhan yang efektif tidak hanya berpengaruh kepada pelanggan namun akan berpengaruh besar terhadap organisasi untuk meningkatkan mutu pelayanan termasuk penghematan biaya yang harus dikeluarkan. Penghematan yang dimaksud adalah pengeluaran operasional organisasi untuk memecahkan masalah seperti kesalahan, keluhan yang sebenarnya dapat dihindari, kelalaian, sistem yang tidak efisien dan tenaga yang kurang terlatih. ${ }^{1}$

Keluhan merupakan ungkapan rasa tidak puas yang dirasakan oleh konsumen terhadap satu produk atau layanan baik secara lisan ataupun tertulis dari pelanggan internal maupun pelanggan eksternal. Pasien sebagai pelanggan eksternal tidak hanya menginginkan kesembuhan dari sakit yang diderita (outcome pelayanan), tetapi juga merasakan dan menilai bagaimana pasien diperlakukan dalam proses pelayanan. Hasil pelayanan kesehatan adalah luaran klinis, manfaat yang diperoleh oleh pelanggan dan pengalaman pelanggan yang berupa kepuasan atau kekecewaan. $^{2}$

Menurut Kotler dan Keller, kepuasan pasien (customer satisfaction) adalah perasaan senang atau kecewa yang didapatkan seseorang dari perbandingan antara kinerja atau hasil produk yang dirasakan (perceived performance) dengan ekspektasi. Apabila pelanggan merasa puas, maka dia akan menunjukkan besarnya kemungkinan untuk kembali menggunakan jasa yang sama. Pelanggan yang puas juga cenderung akan memberikan referensi yang baik terhadap produk dan jasa kepada yang lain, namun apabila pelanggan tidak merasa puas maka akan menjadi suatu ancaman. Pasien akan pindah ke penyedia jasa pelayanan kesehatan lain dan menceritakan pengalamannya kepada orang lain sehingga menimbulkan citra buruk di mata pelanggan lainnya. Apabila ada pelanggan yang mengeluh, hal ini menjadi momen yang baik karena memberikan kesempatan kepada organisasi untuk melakukan pemulihan jasa (service recovery). Pelanggan yang mengeluh bisa berubah menjadi pelanggan yang loyal apabila organisasi dapat menangani keluhan dengan baik. $^{3}$

Keluhan menjadi persoalan di semua negara yang dapat dilihat dari menigkatnya keluhan pasien di dunia, pada National Health Service (NHS) di United Kingdom (UK) pada tahun 2015-2016 terdapat 198.739 keluhan dan meningkat pada tahun berikutnya sebesar 4,9\% menjadi 208.415 keluhan. Pada Hospital and Community Health Service (HCHS) tahun 2017-2018 total laporan komplain tertulis adalah 113.989. Proporsi terbesar dikaitkan dengan layanan rawat inap yaitu sebesar 32,7\%, angka ini menunjukkan peningkatan dari tahun sebelumnya yaitu sebesar $31,3 \%$ dan keluhan juga meningkat pada kategori pengobatan klinis, perilaku tenaga medis dalam memberikan pelayanan dan komunikasi dalam pelayanan. Pada Gloucestershire Hospitals diterima 1031 komplain pada tahun 2017-2018 dan mengalami peningkatan $13 \%$ dari tahun sebelumnya yaitu 913 keluhan. ${ }^{4}$

Keluhan pasien yang terjadi di Indonesia masih banyak, seperti di RSUD Dr Iskak Tulungagung tahun 2011 tercatat 399 keluhan namun tidak semua keluhan dikonfirmasi oleh pihak rumah sakit. ${ }^{5}$ Kasus keluhan juga terdapat di RSUD Masohi, dimana perawat tidak mengawasi jadwal minum obat pasien rawat inap. ${ }^{6}$ Kasus keluhan lain seperti kasus ketepatan jadwal pelayanan di RSUP Dr M Djamil dimana petugas belum komit dalam pelaksanaan pelayanan sesuai jadwal yang telah ditentukan karena dokter datang tidak tepat waktu dan keinginan untuk bertemu dokter yang sama tiap kali kunjungan. ${ }^{7}$ Keluhan lainnya terdapat di RSUD Sijunjung dimana pasien mendapatkan pelayanan yang tidak sopan di ruang rawat inap, yaitu petugas medis memindahkan kasur dengan cara kasar sehingga darah pada infus naik. ${ }^{8}$ Menurut penelitian Irawan et al bahwa faktor penghambat manajemen komplain di RSUD Merauke disebabkan oleh masalah sumber daya manusia. Minimnya keterampilan para petugas rumah sakit dalam menangani komplain, sehingga setiap ada pasien yang komplain maka kabid pelayanan atau 
direktur yang harus memberikan penjelasan hingga pasien mengerti dan dapat menerima solusi yang diberikan pihak rumah sakit. ${ }^{9}$ Survey yang dilakukan terhadapsepuluh rumah sakit pemerintah di Kabupaten/Kota Sumatera Barat tentang pelayanan publik menemukan permasalahan utama menyangkut aspek core business. Secara umum menunjukkan hampir seluruh rumah sakit memiliki gap dalam dimensi keterbukaan/accountability yang menunjukkan manajemen RS dalam menangani keluhan masih terdapat diskriminasi. ${ }^{2}$

RSUD. Rasidin merupakan Rumah Sakit Umum kelas C milik instansi Pemerintah Kota Padang. Rumah sakit ini sebagai rumah sakit rujukan pemerintah yang menerima rujukan dari 23 puskesmas induk, 62 pustu, dan 25 rumah sakit lainnya. Rumah sakit ini memberikan pelayanan kedokteran spesialis yaitu spesialis kandungan, anak, penyakit dalam, bedah, bedah orthopedi, THT, mata, kulit, saraf, jantung dan paru. Pelayanan rawat inap memiliki 145 tempat tidur namun saat ini yang tersedia 108 tempat tidur yang terdiri dari 50 unit untuk kelas keperawatan III, 20 unit untuk kelas keperawatan II, 14 unit untuk kelas keperawatan I, 6 unit untuk kelas isolasi, 3 unit untuk ICU dan 15 unit untuk NICU. ${ }^{10}$

Berdasarkan survey Indeks Kepuasan Masyarakat terhadap pelayanan publik di RSUD Rasidin pada tahun 2018 dengan menggunakan metode Permenpan No. 14 tahun 2017 dengan 9 indikator yaitu persyaratan, system mekanisme dan prosedur, waktu penyelesaian, biaya/tarif, produk spesifikasi jenis pelayanan, kompetensi pelaksana, pelaku pelaksana, penanganan pengaduan, saran dan masukan serta sarana dan prasarana. ${ }^{11}$ Diketahui bahwa rerata kepuasan pasien di RSUD Rasidin secara keseluruhan adalah 2,96 (nilai kurang dari 3) dengan nilai IKM 73,94 (IKM 85) artinya pelayanan belum berada pada kategori puas dan nilai terendah ada pada indikator penanganan pengaduan pengguna layanan dengan nilai 2,33. Adapun rekapitulasi data kepuasan di instalasi rawat inap dengan nilai rerata kepuasan yaitu 3,06 dengan Indeks Kepuasan Masyarakat 76,56 artinya pelayanan belum berada pada kategori puas serta kinerja unit pelayanan kurang baik dengan nilai mutu pelayanan $\mathrm{C}^{12}$ Salah satu dari sembilan indikator permenpen diketahui bahwa indikator yang paling rendah dalam pelayanan rawat inap adalah penanganan pengaduan penggunaan layanan dengan nilai 2,64 maka peneliti akan fokus membahas indikator penanganan pengaduan penggunaan layanan di bagian rawat inap. Data survei pendahuluan yang dilakukan tentang service recovery terhadap pasien rawat inap di Rumah Sakit Provinsi Sumatra Barat yang dilakukakn di enam rumah sakit Padang bahwa RS Rasidin adalah rumah sakit yang paling terendah tingkat kepuasannya terhadap service recovery yang meliputi prosedural justice, interactional justice, dan distributive justice yaitu sebesar $20 \%$.

Berdasarkan uraian diatas, peneliti tertarik untuk melakukan penelitian mengenai "Gambaran Tingkat Kepuasan Pasien Dalam Penanganan Keluhan Rawat Inap di RSUD Rasidin Kota Padang”.

\section{METODE}

Jenis penelitian ini merupakan cross sectional study yang bertujuan untuk melihat tingkat kepuasan pasien dalam penanganan keluhan di RSUD Rasidin Kota Padang. Responden adalah pasien di RSUD Rasidin Kota Padang. Pengumpulan data dilakukan dengan metode survei menggunakan kuisioner terhadap 155 responden rawat inap.

Tingkat kepuasan individu dihitung berdasarkan persepsi per harapan dikali 100\%. Kemudian dilakukan Importance-Performance Analysis diolah dengan bantuan program komputer. Berdasarkan hasil tersebut dimasukkan ke diagram kartesius kemudian dilakukan analisis menurut tingkat kepentingan dan kinerja pelayanan.

\section{HASIL}

\section{Karakteristik Responden}

Berdasarkan penelitian yang telah dilakukan diperoleh informasi mengenai karakteristik pasien rawat inap terdiri dari jenis kelamin, usia, pekerjaan, tingkat pendidikan, tempat tinggal, status rawat pasien dan status pembayaran serta frekuensi menggunakan jasa rawat inap, dapat dilihat dari Tabel 1 sebagai berikut. 
Tabel 1. Karakteristik pasien rawat inap di RSUD Rasidin tahun 2019

\begin{tabular}{|c|c|c|}
\hline Karakteristik Pasien & (f) & $(\%)$ \\
\hline \multicolumn{3}{|l|}{ Jenis Kelamin } \\
\hline Laki-laki & 54 & 34,8 \\
\hline Perempuan & 101 & 65,2 \\
\hline \multicolumn{3}{|l|}{ Tempat Tinggal } \\
\hline Dalam Kota & 151 & 97,4 \\
\hline Luar Kota & 4 & 2,6 \\
\hline \multicolumn{3}{|l|}{ Usia } \\
\hline$<20$ tahun & 25 & 16,1 \\
\hline 20-39 tahun & 53 & 34,2 \\
\hline 40-59 tahun & 38 & 24,5 \\
\hline 60 tahun ke atas & 39 & 25,2 \\
\hline \multicolumn{3}{|l|}{ Frekuensi menggunakan } \\
\hline \multicolumn{3}{|l|}{ jasa rawat inap } \\
\hline 1 Kali & 94 & 60,6 \\
\hline Lebih 1 Kali & 61 & 39,4 \\
\hline \multicolumn{3}{|l|}{ Status pasien } \\
\hline BPJS Pemerintah & 85 & 54,8 \\
\hline BPJS Mandiri & 44 & 28,4 \\
\hline $\begin{array}{l}\text { PBI (Jamkesmas, } \\
\text { Jamkesda) }\end{array}$ & 12 & 7,7 \\
\hline Umum & 13 & 8,4 \\
\hline Jampersal & 1 & 0,6 \\
\hline \multicolumn{3}{|l|}{ Kelas rawatan } \\
\hline I & 1 & 0,6 \\
\hline II & 5 & 3,2 \\
\hline III & 149 & 96,1 \\
\hline \multicolumn{3}{|l|}{ Kategori Pasien } \\
\hline Rujukan & 57 & 36,8 \\
\hline Tidak Rujukan & 98 & 63,2 \\
\hline \multicolumn{3}{|l|}{ Pendidikan } \\
\hline $\begin{array}{l}\text { Belum/ } \\
\text { Tidak Tamat SD }\end{array}$ & 14 & 9,0 \\
\hline SD/Sederajat & 39 & 25,2 \\
\hline SMP/Sederajat & 33 & 21,3 \\
\hline SMA/Sederajat & 50 & 32,3 \\
\hline Sarjana & 13 & 8,4 \\
\hline Tidak Sekolah & 6 & 3,9 \\
\hline \multicolumn{3}{|l|}{ Pekerjaan } \\
\hline Pegawai Swasta & 2 & 1,3 \\
\hline Pedagang & 5 & 3,2 \\
\hline Petani & 16 & 10,3 \\
\hline Mahasiswa/Pelajar & 13 & 8,4 \\
\hline Tidak/ Belum Bekerja & 119 & 76,8 \\
\hline
\end{tabular}

Tabel 1 dapat diketahui bahwa karakteristik pasien rawat inap di RSUD Rasidin tahun 2019 adalah lebih dari separuh responden berjenis kelamin perempuan $(65,2 \%)$, berdasarkan kelompok umur paling banyak berumur antara 20-39 tahun (53\%), berdasarkan pekerjaan paling banyak yaitu tidak/belum bekerja (76,8\%), berdasarkan tingkat pendidikan paling banyak yaitu SMA/Sederajat (32,3\%), sedangkan berdasarkan tempat tinggal lebih dari separuh responden bertempat tinggal di dalam kota $(97,4 \%)$, berdasarkan status rawat pasien lebih dari separuh responden merupakan pasien baru $(60,6 \%)$ dan berdasarkan status pembayaran lebih dari separuh responden melakukan pembayaran menggunakan BPJS kesehatan yang dibayarkan pemerintah $(54,8 \%)$.

\section{Gambaran tingkat kepuasan pasien dalam penanganan keluhan rawat inap di RSUD Rasidin}

Berdasarkan penelitian, didapatkan hasil survei mengenai kepuasan pasien dalam penanganan keluhan rawat inap di RSUD Rasidin dapat dilihat sebagai berikut.

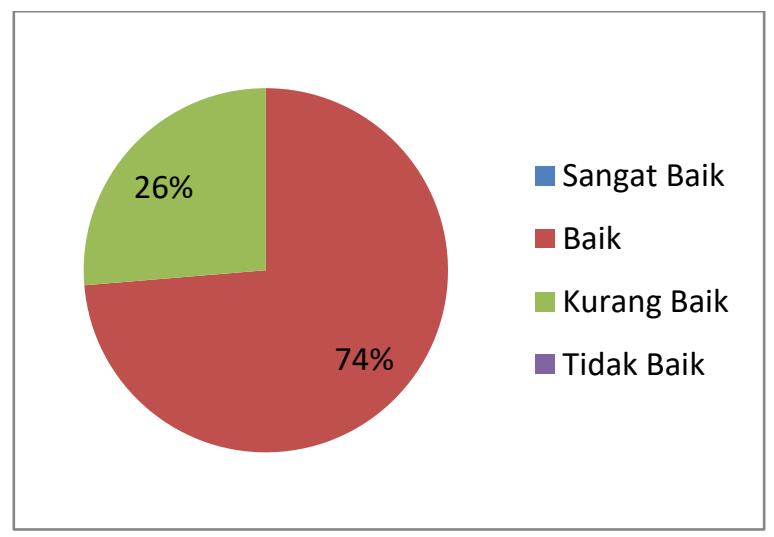

Gambar 1. Tingkat kepuasan pasien di rawat inap RSUD Rasidin tahun 2019

Pada penelitian ini terlihat persentase pasien rawat inap yang mendapatkan pelayanan kesehatan yang baik di RSUD Rasidin tahun 2019 sebanyak $74 \%$, sedangkan pasien yang mendapatkan pelayanan yang kurang baik sebanyak $26 \%$. 
Tabel 2. Tingkat persepsi dan harapan pasien rawat inap pada setiap atribut yang mempengaruhi kepuasan dalam penanganan keluhan pasien rawat inap di RSUD Rasidin tahun 2019

\begin{tabular}{|c|c|c|c|c|}
\hline No & Dimensi Mutu Pelayanan & $\overline{\mathbf{X}}$ & $\overline{\mathbf{Y}}$ & Tki (\%) \\
\hline \multicolumn{5}{|c|}{ Procedural Justice } \\
\hline 1 & Memiliki alur pelayanan yang jelas & 3,89 & 4,75 & 81,93 \\
\hline 2 & Prosedur pelayanan tidak berbelit-belit & 3,88 & 4,76 & 81,57 \\
\hline 3 & Pelayanan yang diberikan cepat, tepat, dan memadai & 3,75 & 4,79 & 78,30 \\
\hline 4 & $\begin{array}{l}\text { Memberikan waktu yang cukup bagi pasian/keluarga pasien untuk } \\
\text { berkonsultasi }\end{array}$ & 3,55 & 4,82 & 73,76 \\
\hline \multicolumn{5}{|c|}{ Interactional Justice } \\
\hline 5 & Memiliki tenaga medis yang memiliki sikap yang ramah & 3,82 & 4,85 & 78,72 \\
\hline 6 & Tidak membuat pasien menunggu terlalu lama & 3,74 & 4,86 & 76,89 \\
\hline 7 & Komunikasi antara pasien dengan dokter berlangsung baik & 3,70 & 4,90 & 75,39 \\
\hline 8 & Komunikasi antara pasien dengan perawat berlangsung baik & 3,90 & 4,88 & 79,79 \\
\hline 9 & $\begin{array}{l}\text { Dokter memberikan informasi mengenai masalah kesehatan penyakit } \\
\text { yang diderita }\end{array}$ & 3,47 & 4,91 & 70,70 \\
\hline 10 & $\begin{array}{l}\text { Perawat memberikan informasi mengenai masalah kesehatan penyakit } \\
\text { yang diderita }\end{array}$ & 3,57 & 4,91 & 72,80 \\
\hline 11 & Membantu pasien secara tulus dan ikhlas dalam mengatasi masalah & 3,85 & 4,87 & 78,94 \\
\hline 12 & $\begin{array}{l}\text { Petugas/karyawan menunjukkan empati dan cepat tanggap dalam } \\
\text { memberikan pelayanan }\end{array}$ & 3,79 & 4,86 & 77,98 \\
\hline 13 & $\begin{array}{l}\text { Petugas/karyawan memberikan informasi nomor kontak /kotak kritik } \\
\text { untuk menyampaikan keluhan pasien dan keluarga }\end{array}$ & 3,83 & 4,86 & 78,65 \\
\hline 14 & Cepat dan tepat dalam menangani keluhan pasien & 3,80 & 4,86 & 78,12 \\
\hline \multicolumn{5}{|c|}{ Distributive Justice } \\
\hline 15 & Pelayanan yang saya terima adil dan tidak membedakan pasien & 3,97 & 4,89 & 81,27 \\
\hline 16 & $\begin{array}{l}\text { Pasien mendapatkan pelayanan dengan baik dalam pengobatan } \\
\text { penyakit pasien }\end{array}$ & 3,86 & 4,90 & 78,68 \\
\hline 17 & Dokter selalu menanyakan keluhan pasien & 3,57 & 4,93 & 72,51 \\
\hline 18 & Perawat selalu memberi obat pasien sesuai prosedur pemberian obat & 3,94 & 4,90 & 80,50 \\
\hline 19 & $\begin{array}{l}\text { Perawat segera menghubungi dokter mengenai obat dan makanan } \\
\text { pasien }\end{array}$ & 3,97 & 4,86 & 81,70 \\
\hline
\end{tabular}

Tabel 2 menunjukan bahwa kepuasan terendah dalam indikator penanganan keluhan terdapat pada poin ke 4 tentang memberikan waktu yang cukup bagi pasian/keluarga pasien untuk berkonsultasi (73,76\%), poin ke 9 tentang dokter memberikan informasi mengenai masalah kesehatan penyakit yang diderita $(70,70 \%)$, poin ke 10 tentang perawat memberikan informasi mengenai masalah kesehatan penyakit yang diderita $(72,80)$ dan poin ke 17 tentang dokter menanyakan keluhan pasien (72,51\%).

Atribut persepsi dan harapan pasien rawat inap yang mempengaruhi kepuasan pasien dapat dilihat pada diagram kartesius Gambar 2. 


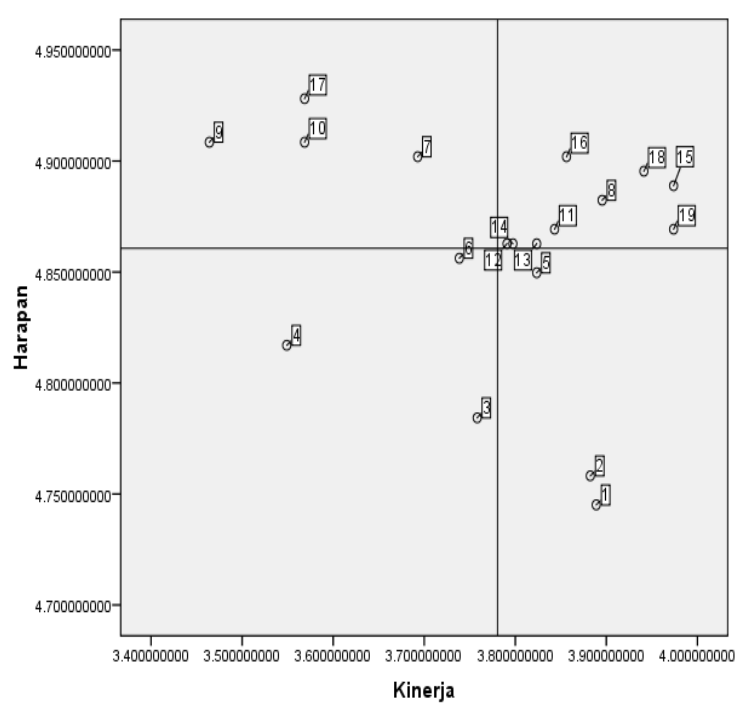

Gambar 2. Diagram kartesius atribut persepsi dan harapan pasien rawat inap yang mempengaruhi kepuasan pasien di RSUD Rasidin tahun 2019

Keterangan: $X=$ rerata persepsi pasien

$$
\mathrm{Y}=\text { rerata harapan pasien }
$$

Berdasarkan Gambar 2 dapat terlihat bahwa letak atribut yang mempengaruhi kepuasan pasien di RSUD Rasidin terbagi atas 4 kuadran yaitu prioritas utama (kuadran A), prioritas pertahankan prestasi (kuadran B), prioritas rendah (kuadran C) dan prioritas lebih (kuadran D). Selanjutnya setiap kuadran dijelaskan pada tabel berikut.

Tabel 3. Atribut yang masuk dalam kuadran A (prioritas utama)

\begin{tabular}{|c|c|c|}
\hline No & Atribut di Kuadran A & Tki (\%) \\
\hline 9 & $\begin{array}{l}\text { Dokter memberikan informasi mengenai } \\
\text { masalah kesehatan penyakit yang } \\
\text { diderita }\end{array}$ & 70,70 \\
\hline 17 & $\begin{array}{l}\text { Dokter selalu menanyakan keluhan } \\
\text { saya }\end{array}$ & 72,51 \\
\hline 10 & $\begin{array}{l}\text { Perawat memberikan informasi } \\
\text { mengenai masalah kesehatan penyakit } \\
\text { yang diderita }\end{array}$ & 72,80 \\
\hline 7 & $\begin{array}{l}\text { Komunikasi antara pasien dengan } \\
\text { dokter berlangsung baik }\end{array}$ & 75,39 \\
\hline
\end{tabular}

Tabel 4. Atribut yang masuk dalam kuadran B (prioritas pertahankan prestasi)

\begin{tabular}{|c|c|c|}
\hline No & Atribut di Kuadran B & Tki (\%) \\
\hline 12 & $\begin{array}{l}\text { Petugas/karyawan menunjukkan empati } \\
\text { dan cepat tanggap dalam memberikan } \\
\text { pelayanan }\end{array}$ & 77,98 \\
\hline 14 & $\begin{array}{l}\text { Cepat dan tepat dalam menangani } \\
\text { keluhan pasien }\end{array}$ & 78,12 \\
\hline 13 & $\begin{array}{l}\text { Petugas/karyawan memberikan } \\
\text { informasi nomor kontak /kotak kritik } \\
\text { untuk menyampaikan keluhan pasien } \\
\text { dan keluarga }\end{array}$ & 78,65 \\
\hline 16 & $\begin{array}{l}\text { Saya mendapatkan pelayanan dengan } \\
\text { baik dalam pengobatan penyakit saya }\end{array}$ & 78,68 \\
\hline 11 & $\begin{array}{l}\text { Membantu pasien secara tulus dan } \\
\text { ikhlas dalam mengatasi masalah }\end{array}$ & 78,94 \\
\hline 8 & $\begin{array}{l}\text { Komunikasi antara saya dengan perawat } \\
\text { berlangsung baik }\end{array}$ & 79,79 \\
\hline 18 & $\begin{array}{l}\text { Perawat selalu memberi obat pasien } \\
\text { sesui prosedur pemberian obat }\end{array}$ & 80,50 \\
\hline 15 & $\begin{array}{l}\text { Pelayanan yang saya terima adil dan } \\
\text { tidak membedakan pasien }\end{array}$ & 81,27 \\
\hline 19 & $\begin{array}{l}\text { Perawat segera menghubungi dokter } \\
\text { mengenai obat dan makanan pasien }\end{array}$ & 81,70 \\
\hline
\end{tabular}

Tabel 4. Atribut yang masuk dalam kuadran C (prioritas rendah)

\begin{tabular}{lll}
\hline No & Atribut di Kuadran C & Tki (\%) \\
\hline 4 & $\begin{array}{l}\text { Memberikan waktu yang cukup bagi } \\
\text { pasian/keluarga pasien untuk }\end{array}$ & 73,76 \\
& $\begin{array}{l}\text { berkonsultasi } \\
6\end{array}$ & $\begin{array}{l}\text { Tidak membuat pasien menunggu terlalu } \\
\text { lama }\end{array}$ \\
3 & $\begin{array}{l}\text { Pelayanan yang diberikan cepat, tepat, } \\
\text { dan memadai }\end{array}$ & 78,30 \\
\hline
\end{tabular}

Tabel 5. Atribut yang masuk dalam kuadran D (prioritas lebih)

\begin{tabular}{lll}
\hline No & Atribut di Kuadran D & Tki (\%) \\
\hline 5 & Memiliki tenaga medis yang memiliki & 78,72 \\
& sikap yang ramah & \\
2 & Prosedur pelayanan tidak berbelit-belit & 81,57 \\
1 & Memiliki alur pelayanan yang jelas & 81,93 \\
\hline
\end{tabular}


Berikut ini adalah pemetaan alur permasalahan keluhan di RSUD Rasidin

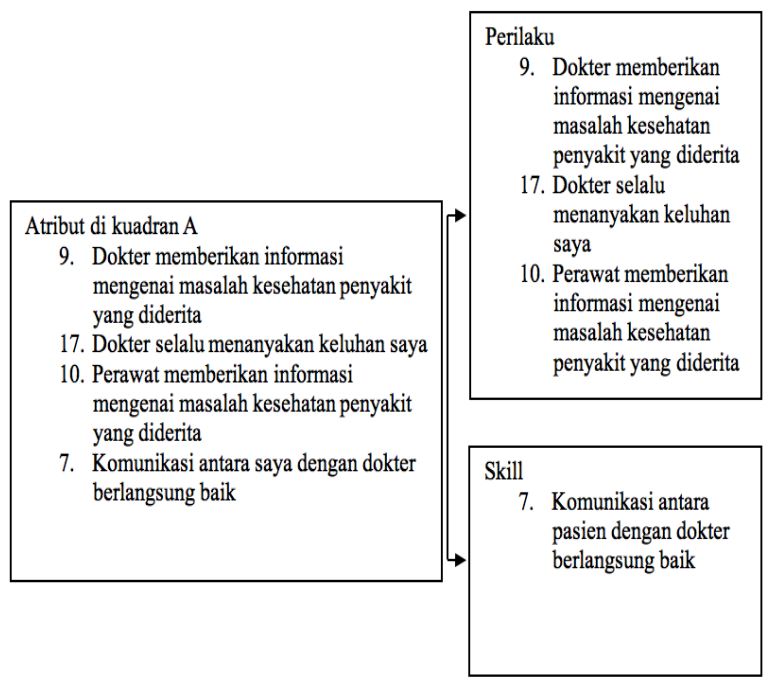

Gambar 3. Pemetaan alur permasalahan keluhan rawat inap terhadap pelayanan kesehatan di RSUD Rasidin tahun 2019

Pada gambar pemetaan alur permasalahan diatas, atribut dikuadran dibagi pada dua kelompok yaitu perilaku dan skill. Pada kelompok perilaku petugas yaitu dokter memberikan informasi mengenai masalah kesehatan penyakit yang diderita, dokter selalu menanyakan keluhan pasien, perawat memberikan informasi mengenai masalah kesehatan penyakit yang diderita. Komunikasi pada kelompok skill antara pasien dengan dokter berlangsung baik.

\section{PEMBAHASAN}

\section{Tingkat Kepuasan Pasien di Rawat Inap RSUD Rasidin Tahun 2019}

Gambaran tingkat kepuasan pelayanan yang diterima responden terlihat dari persentase sebanyak $74 \%$ responden mendapatkan pelayanan yang baik dan $26 \%$ responden mendapatkan pelayanan yang kurang baik. Tingkat kepuasan pelayanan adalah persepsi kepuasan pasien terhadap pelayanan yang mereka rasakan selama menjalani perawatan di instalasi rawat inap RSUD Rasidin. Kondisi ini menunjukkan bahwa sebagian besar pasien merasa puas dengan pelayanan, namun belum terlaksana secara maksimal, sehingga masih ada pasien yang belum merasa puas dalam pelayanan. Dalam mencapai tujuan pelayanan yang berorientasi pada kepuasan pasien maka perlu diperhatikan hal yang berperan penting dalam menentukan persepsi pasien antara lain meliputi fasilitas, peran dokter, tenaga medis dan perawat. ${ }^{13}$

\section{Importance Performance Analysis}

Hasil uji Importance Performance Analysis menunjukkan beberapa atribut pada kuadran A yang menjadi prioritas utama untuk ditingkatkan karena atribut yang terletak di kuadran ini dianggap sebagai faktor yang sangat penting oleh konsumen namun kondisi saat ini belum memuaskan. Ada 4 atribut yang menjadi prioritas utama untuk ditingkatkan yaitu keahlian dokter dalam memberikan informasi mengenai masalah kesehatan penyakit yang diderita pasien, keahlian doker dalam menanyakan keluhan pasien, keahlian perawat dalam memberikan informasi mengenai masalah kesehatan penyakit yang diderita pasien dan komunikasi antara pasien dengan dokter. Keempat atribut ini lebih menekankan kepada perilaku dan apek komunikasi tenaga medis dengan pasien yang kurang baik. Menurut Arwani, aspek komunikasi merupakan sikap petugas kesehatan yang harus mampu melakukan komunikasi sebaik mungkin dengan pasien dan keluarga pasien. Pengucapan salam saat bertemu dan berpisah dengan pasien merupakan salah satu cara untuk menyatu dengan pasien dan keluarga pasien. ${ }^{14}$

Petugas saat melakukan pelayanan kesehatan seharusnya menggunakan keterampilan komunikasi yang baik pada pasien dan keluarga pasien. Dampak buruk yang timbul seperti penyampaian keluhan melalui media massa dan media elektronik akan terhenti. Keluhan yang disampaikan ini tentunya dapat merugikan rumah sakit, karena berawal dari keluhan yang tidak tertangani, menyebabkan berkembangnya isu di masyarakat yang meragukan pelayanan di rumah sakit.

\section{SIMPULAN}

Tingkat kepuasan pasien dalam penanganan keluhan rawat inap di RSUD Rasidin Kota Padang menunjukkan hasil pelayanan kurang baik sebanyak $26 \%$. Ada beberapa keluhan yang harus menjadi prioritas utama untuk ditingkatkan yang berasal dari atribut Interactional Justice dan Distributive Justice. 


\section{SARAN}

RSUD Rasidin agar melakukan perbaikan dari segi kemampuan komunikasi tenaga kesehatan dengan memberikan pelatihan kepada seluruh petugas rumah sakit seperti pelatihan handling complaint, service excellent dan komunikasi efektif sehingga seluruh petugas mampu melakukan pelayanan serta pasien merasa puas dalam pelayanan yang diberikan.

\section{UCAPAN TERIMAKASIH}

Terimaksih kepada RSUD Rasidin Kota Padang beserta jajarannya. Terimakasih kepada ibu pembimbing yang telah banyak membantu dalam memberikan arahan dan saran, serta tak lupa pula terimaksih kepada semua pihak yang telah memberikan motivasi, bimbingan dan bantuan kepada penulis dalam menyelesaikan tulisan ini.

\section{DAFTAR PUSTAKA}

1. Pohan IS. Jaminan mutu layanan kesehatan: dasar-dasar pengertian dan penerapan. Jakarta: EGC; 2007.hlm.144-54.

2. Machmud $R$, Savitri $R$, Mardanus A, Fitria $Y$, Maryeti, Isniati, et al. Survey terhadap 10 rumah sakit pemerintah di Kabupaten Sumatra Barat tahun 2012 dalam penanganan keluhan pasien. Jurnal Kebijakan Kesehatan Indonesia. 2012

3. Kotler P, Keller KL. Manajemen pemasaran. Edisi ke-13 Jilid 1: Jakarta: Erlangga; 2009.

4. National Health Service (NHS). Annual complaint report of NHS. UK: NHS; 2017.

5. Subekti DSMP. Manajemen komplain pelanggan dalam rangka peningkatan pelayanan di RSUD Dr Iskak Tulungagung. Journal Universitas Airlangga. 2013;1(01):47-55.
6. Latupono A, Maidin MA, Zulkifli A, Hubungan mutu pelayanan terhadap kepuasan pasien rawat jalan di RSUD Masohi tahun 2014. JST Kesehatan. 2014;5(1):74-81.

7. Machmud R, Maryeti, Isniati, Abdiana. Survei kepuasan dan manajemen keluhan pasien diabetes melitus terhadap pelayanan kesehatan prolanis askes di RSUP Sumatra Barat. Jurnal Kebijakan Kesehatan Indonesia. 2014;3(3):164-71.

8. Susanti R. Analisis hubungan mutu pelayanan dan manajemen penanganan keluhan dengan kepuasan pasien di ruang rawat inap RSUD Sijunjung [tesis]. Prodi Kesehatan Masyarakat Fakultas Kedokteran Universitas Andalas; 2017.

9. Irawan A, Nawawi J dan Ahmad B. Manajemen komplain pelayanan kesehatan di RSUD Marauke. Elektronik Journal Universitas Musamus Merauke. 2016;5(01):22-31.

10. RSUD Rasidin. Laporan Tahunan RSUD Rasidin tahun 2017. Padang: RSUD Rasidin; 2017.

11. Kementerian Pendayagunaan Aparatur Negara (Kemenpan). Keputusan menteri pendayagunaan aparatur negara (Kepmenpan) no. 14 tahun 2017 tentang pedoman penyusunan survey kepuasan masyarakat unit penyelenggara pelayanan publik. Jakarta: Kemenpan; 2017.

12. RSUD Rasidin. Laporan survey standar pelayanan minimum waktu tunggu dan kepuasan pelanggan RSUD Rasidin tahun 2018. Padang: RSUD Rasidin; 2018.

13. Supriyanto $Y$, Soesanto $H$. Analisis pengaruh kualitas pelayanan, harga, dan fasilitas terhadap kepuasan pasien rawat jalan di rumah sakit Kariadi Semarang. Diponegoro Journal Of Management. 2012;1(1):472-80.

14. Arwani. Komunikasi dalam keperawatan. Jakarta: EGC; 2002.hlm.18-31. 